\title{
Partners in history: The Dutch Reformed Church and theological training at the University of Pretoria: 1938-2000
}

\begin{tabular}{|c|c|}
\hline \multicolumn{2}{|c|}{$\begin{array}{l}\text { Author: } \\
\text { Johan van der Merwe }{ }^{1}\end{array}$} \\
\hline \multicolumn{2}{|c|}{$\begin{array}{l}\text { Affiliation: } \\
{ }^{1} \text { Department of Church } \\
\text { History and Church Polity, } \\
\text { Faculty of Theology, } \\
\text { University of Pretoria, } \\
\text { South Africa }\end{array}$} \\
\hline \multicolumn{2}{|c|}{$\begin{array}{l}\text { Project leader: J.M. van der } \\
\text { Merwe } \\
\text { Project number: } 02383810\end{array}$} \\
\hline \multicolumn{2}{|c|}{$\begin{array}{l}\text { Description: } \\
\text { This research is part of the } \\
\text { project, 'Ecumenical Church } \\
\text { Polity', directed by Prof. Dr } \\
\text { Johan van der Merwe, } \\
\text { Department of Church } \\
\text { History and Church Polity, } \\
\text { Faculty of Theology, } \\
\text { University of Pretoria. }\end{array}$} \\
\hline \multicolumn{2}{|c|}{$\begin{array}{l}\text { Corresponding author: } \\
\text { Johan van der Merwe, } \\
\text { johan.vdmerwe@up.ac.za }\end{array}$} \\
\hline \multicolumn{2}{|c|}{$\begin{array}{l}\text { Received: } 29 \text { Apr. } 2016 \\
\text { Accepted: } 09 \text { Apr. } 2016 \\
\text { Published: } 31 \text { Aug. } 2016\end{array}$} \\
\hline \multicolumn{2}{|c|}{$\begin{array}{l}\text { How to cite this article: } \\
\text { Van der Merwe, J., 2016, } \\
\text { 'Partners in history: The } \\
\text { Dutch Reformed Church and } \\
\text { theological training at the } \\
\text { University of Pretoria: } \\
\text { 1938-2000', HTS Teologiese } \\
\text { Studies/Theological Studies } \\
72(4) \text {, a3416. http://dx.doi. } \\
\text { org/10.4102/hts.v72i4.3416 }\end{array}$} \\
\hline \multicolumn{2}{|c|}{$\begin{array}{l}\text { Copyright: } \\
\text { (C) 2016. The Authors. } \\
\text { Licensee: AOSIS. This } \\
\text { is licensed under the } \\
\text { Creative Commons } \\
\text { Attribution License. }\end{array}$} \\
\hline \multicolumn{2}{|l|}{ Read online: } \\
\hline 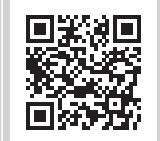 & $\begin{array}{l}\text { Scan this QR } \\
\text { code with your } \\
\text { smart phone or } \\
\text { mobile device } \\
\text { to read online. }\end{array}$ \\
\hline
\end{tabular}

\begin{abstract}
The Faculty of Theology at the University of Pretoria celebrates its centenary in 2017. Theological training at the university started in 1917 when the Nederduitsch Hervormde Kerk van Afrika decided to train its own ministers. In 1937 the Dutch Reformed Church decided to establish a faculty of its own at the university. This led to a faculty with two sections: Section A for the Nederduitsch Hervormde Kerk and Section B for the Dutch Reformed Church. This was the situation until 2000 when the two faculties merged to become one. Although theological training by the Dutch Reformed Church only started in 1938, their faculty, Section B was an important partner through the 100 years of theological training. This article gives a chronology of the history of the Faculty of Theology Section B as partner in the history of theological training at the University of Pretoria.
\end{abstract}

\section{Introduction}

Preparations for the first theological training at the University of Pretoria started in 1917 when the Nederduitsch Hervormde Kerk van Afrika approved the appointment of Dr J.H. Greyvenstein as professor at the then Transvaalse Universiteits Kollege (Engelbrecht 1953:369). Until 1938 the Nederduitsch Hervormde Kerk van Afrika was the only church which trained its ministers at the University of Pretoria (Engelbrecht 1953:369). The situation changed in 1938 when the Dutch Reformed Church also decided to establish its own Faculty of Theology at the University of Pretoria. The government could not allow two faculties of theology at the same university and the problem was solved by dividing the Faculty of Theology at the University of Pretoria into two sections: The Faculty of Theology Section A for the Nederduitsch Hervormde Kerk van Afrika and The Faculty of Theology Section B for the Nederduitse Gereformeerde Kerk van Transvaal (Dutch Reformed Church of Tranvaal). Each section had its own dean, lecturers and departments (Van der Watt 1987:178). A merger between the two faculties took place in 2000 to form one Faculty of Theology at the University of Pretoria (Van der Merwe 2013:51). Although the Faculty of Theology celebrates its centenary in 2017 because 1917 was the year in which theological training was introduced to the University of Pretoria, the Dutch Reformed Church only became a partner in this history in 1938. This article gives an overview of the history of theological training by the Dutch Reformed Church as partner in the 100 years of theological training at the University of Pretoria.

\section{Founding of the Faculty of Theology Section B}

'The 50th anniversary of the Faculty of Theology of The Dutch Reformed Church at the University of Pretoria was both an important and joyous event'. With these words the then rector, Prof. D.M. Joubert congratulated the faculty with its jubilee in 1988 (Joubert 1988:3). Prof. Joubert did not only mention the past. In his message of congratulations he also made mention of the future when saying that the university had specific expectations about the future of the faculty (Joubert 1988:3).

Van der Merwe compares the founding of the of the Faculty of Theology of the Dutch Reformed Church at the University of Pretoria with a fountain which originated in 1938 to became a small stream and which grew into a river which fed church and society through decades of history (Van der Merwe \& Vos 2008:4).

Until the founding of the Faculty of Theology in Pretoria in 1938, the Dutch Reformed Church had only one training facility for ministers of the church. That was the Theological Seminary in Stellenbosch which was established in 1859. Although the Dutch Reformed Church consisted of the Dutch Reformed Churches in the Transvaal, the Orange Free State, Natal and the Cape, all the 
ministers for these churches were trained in Stellenbosch. The fear of further division between the churches was one of the biggest obstacles in the way of a faculty for theology in the northern part of the country. This is confirmed by a decision of the 1934 synod of the church to appoint a commission to address this specific problem (Handelinge 1934:373).

The establishment of the faculty did not happen overnight. Dr W. Nicol described it correctly when he wrote: 'The Faculty of Theology went through a long struggle in the womb of the church before it was born' (Nicol 1946:7). The two persons who made the first approach for a faculty in Pretoria were D.F. du Toit Malherbe and W.P. de Villiers. These two lecturers at the University of Pretoria tabled a proposal at the 11th synod of the Nederduitsch Hervormde of Gereformeerde Kerk van Zuid Afrika which took place in May 1916. The proposal was however turned down without any discussion (Nicol 1946:7). The matter was taken up again in 1919 when the Board of the Transvaalse Universiteits College sent a letter to the Synodical commission in which they asked that the synod should consider the appointment of one or more professors in theology. In their reaction the Commission stated that they did not see the need for the establishment of one or more chairs in theology at the Transvaalse Universiteits College (Handelinge 1919:18). It was however not the end of the matter. During the synod of 1922, Rev. Paul Nel proposed that a commission should be appointed to investigate the matter. The proposal was turned down by 88 votes against 50 (Handelinge 1922:62).

Rapid change in church and society led to a change of heart in the church. The consequences of and the end of the first World War in 1918, industrialisation in Transvaal, the migration of many members of the church to the cities and the rapid growth of Afrikaans student numbers at the University of Pretoria necessitated the establishment of a Faculty of Theology in the northern part of the country (Van der Watt 1988:8). Political change also played a part. The thirties saw the growth of Afrikaner nationalism which was strengthened by the celebration of the centenary of the Great Trek in 1938 and the building of the Voortrekker Monument (Ferreira 1970:5).

In 1934 the synod took a watershed decision namely to investigate the establishment of a faculty of Theology in Transvaal. Listed under Belangrike Besluite [important decisions] the decision was communicated with members of the church in the following way: 'The synod is convinced that the time has come for the Transvaal church to appoint its own professors at the University of Pretoria to provide training for our own ministers'. A decision on this matter was taken nearly unanimously and a commission has been appointed to prepare the way for the implementation of this decision. Where we, in the past feared that this issue could lead to division in the church, the discussion took place in an atmosphere of love and cooperation (Handelinge 1934:373). The members of the commission were: Reverends W. Nicol, J.I. de Wet, Dr J.H. Eybers, Reverends Paul Nel, J.H.M. Stofberg, P. van der Hoven and G.D. Worst (Verslag 1937:1).
The task of the commission was to negotiate with the Dutch Reformed Church in the Cape in order to ensure unity and cooperation, to negotiate with the university, to inform congregations, to acquire the necessary funding and to negotiate with government about possible state subsidy (Verslag 1937:2). The report of the commission was published as a brochure 6 months ahead of the 1937 synod. In the report the commission proposed that the church should proceed to make it possible for the training of ministers at the University of Pretoria (Verslag 1937:54).

After a lengthy debate, the proposals of the commission were tabled on Friday, 16 April 1937. Synod decided with 139 votes against 68 that: 'the church should go ahead to provide for the training of ministers at the University of Pretoria' (Handelinge 1937:54). After dinner, the meeting took an important turn when the minister of Wolmaransstad read a declaration on behalf of the 68 members who voted against the proposal. In the declaration they emphasised that they do not give up their principles, but that they accept the decision of the synod for the sake of the King of the church and that they undertake to promote the decision as far as possible (Handelinge 1937:55). What happened next is described by van der Watt (1988:12) as an emotional climax when the meeting proceeded with spontaneous prayer and the singing of the last verse of Hymn 65:

Verlosten, juicht! Hebt Jesus lief,

Dat wij ons zaam in dat gevoel vereenen,

Laat dankbaarheid aan zijne voete weenen

Wie, wie verdient die tranen, zoo als Hij?

The road was now open for the establishment of a faculty of Theology for the Dutch Reformed Church in Transvaal. The Commission for the Theological Faculty convened on 9 December 1937 in the Voortrekkergedenksaal in Pretoria to name professors for appointment by the Board of the University of Pretoria. G.M. Pellisier was named as professor in Science of Religion, E.P. Groenewald as professor in New Testament, D..J Keet as professor in Church history and J.H. Kritzinger as professor in Old Testament (Van der watt 1988:13). The faculty was officially opened when these professors were inaugurated on 16 March 1938 in the church building of the Dutch Reformed congregation Pretoria East. The Faculty of Theology Section B was now a reality. Six students registered at the new faculty namely: J.P. Grobler, J.M. Louw, R.B. Murray, J.P. Theron, A.A. van Wyk and L.L.J. Visser (van der Watt 1987:178). The importance of this event is described by one of the first students, Rev. AA van Wyk:

It was 1938 - the Voortrekker centenary year - when the Theological faculty of our church was established. We had to find our way with our new professors. In faith and with courage they went forward and we followed. Their dedication gave us assurance that they were God given ... If I had to go back to 1935 and choose again, I would choose the Faculty of Theology in Pretoria without any doubt. (Van Wyk 1946:26)

Van Wyk's reference to 1938 - the Voortrekker centenary year confirms the fact that the establishment of the faculty could not be separated from the growing Afrikaner nationalism. 


\section{Growth of the faculty} Student numbers

In the first decade of the Faculty of Theology Section $B$, student numbers grew steadily. This is confirmed by one of the first professors when he remarked: 'Student numbers are growing fast' (Groenewald 1946:11). The student numbers were indeed increasing year by year. In 1945 there were 27 students and in 1946, 30 (Groenewald 1946:11). The faculty reached an important milestone in 1970 when more than 100 students were registered (Hofmeyer 1971:35). Student numbers kept growing. The Kuratorium reported to the General Synod of the Dutch Reformed Church in 1978 that there were 327 theology students and 209 admission students registered at the faculty. A further 102 students were busy with doctoral studies (Handelinge 1978:703). The growth in numbers not only meant that the faculty would have a huge influence in church and society. It also had an immediate influence on the university itself. According to Groenewald (1946:12) it was the professors who played a big role at the university. 'In times of conflict and crises they had the opportunity to make sure that peace and justice prevail'. The growth in student numbers and the role which the professors played confirm the fact that the decision to start a faculty of Theology in the northern part of the country was the right decision.

\section{More lecturers for the faculty}

The growth in student numbers also meant that the work load of the four professors became too heavy. An important decision to stimulate the growth of the faculty was to increase the number of professors at the faculty. The first step in this direction came with the retirement of Prof. G.M. Pellisier in 1946. The decision was taken to use him as professor in 'kerklike vakke' [church subjects]. A.B. du Preez was appointed as professor in Dogmatics in the same year (Hofmeyer 1971:32). Not only did this arrangement lighten the load of the lecturers, it also allowed them to specialise in their own fields of expertise (Groenewald 1962:29). The opportunity to specialise was one of the important arguments to expand the number of lecturers even further. In 1948 a fifth department namely the department for Science of Religion and Missiology was established. After the final retirement of G.M. Pellisier in 1952, H.D.A. du Toit was appointed in 1953 as professor in the new department. He was also responsible for teaching Practical Theology (Hofmeyer 1971:32). When Prof. D.J. Keet retired in 1954 Prof. B.J. Marais was appointed in his place. Practical Theology became an independent department in 1967 when Prof. C.W.H. Boshoff was appointed as professor in Science of Missiology. Prof. A.H. van Zyl was appointed in the department of Old Testament in 1966 when Prof. J.H. Kritzinger retired. More lecturers would follow. J.A. Heyns and A.B. du Toit were appointed in 1971; J.J. de Klerk in 1973 and P.B. van der Watt in 1975 after Prof. B.J. Marais retired (van der Watt 1988:17). With the increase in student's numbers, six more lecturers were appointed in 1975. This confirmed the important place the faculty held in church and society (Handelinge 1978:702). The lecturers who were appointed were A.C. Barnard, F.J. Botha, C.F.A. Borchardt, D. Crafford, W.S. Prinsloo, P.C. Potgieter, J.A. du Randt, M.H.O. Kloppers and H.J.C. Pieterse. By 1978 the total staff component of the faculty was:

- Old Testament: Professors A.H. van Zyl, W.S. Prinsloo and Rev. M.H.O.Kloppers

- New Testament: Professors A.B. du Toit, F.J. Botha and Dr J.A. du Randt

- Dogmatics: Professors J.A. Heys and P.C. Potgieter

- Church History: Professors P.B. van der Watt and C.F.A. Borchardt

- Science of Missiology: Professors C.W.H. Boshoff and D. Crafford

Practical Theology: Professors J.J. de Klerk, A.C. Barnard and Rev. H.J.C. Pieterse (Handelinge 1978:703).

\section{An own building for the Faculty of Theology Section B}

As the faculty grew, the needs of the faculty became more. After only 8 years Prof. J.H. Kritzinger wrote in 1946 that: 'certain needs of the faculty have become so acute that we have to direct the attention of the members of the church to it' (Kritzinger 1946:13). He explained in his letter that the faculty was cramped for space. Lecture halls were too small and there was a big shortage in office space. A shortage of bursaries for students was also named as one of the major short comings in the theological training of the church. Kritzinger wrote: 'If somebody has to complete his study of 7 years on borrowed money, he goes into ministry with debt which will impoverish him and his family for the rest of his ministry'. He then mentioned that the cost of theological training was up to 120 pounds per year (Kritzinger 1946:14). Kritzinger also asked for books for the faculty.

Out of all the needs which were mentioned, the shortage of lecture halls was the biggest frustration. Although the agreement between the university and the church, stated that the university had to provide the necessary infrastructure for the faculty of Theology, it became a serious problem. Initially a room was provided in the Old Club Hall. As numbers grew, two washing rooms in the Old Arts building were renovated as classrooms and when they became too small, the Inter hall was used (Hofmeyer 1971:36). Student numbers which grew steadily made new facilities a priority and forced the Transvaal synod of the Dutch Reformed Church to take up the challenge of finding funds to build a building for the faculty. Under the leadership of Rev. P.J. Swart members of the church, congregations and businesses were approached and the donations and collections soon reached the 30000 pound mark. Eventually, 50000 pounds were donated to the University of Pretoria for the construction of a building for theology. During the Transvaal synod of 1951, a memorial plate was unveiled at the entrance of the new Arts building where the faculty was housed. The building was initially shared with the Faculty of Education but officially became the Theology building on 31 August 1983 after the intervention 
of the then rector, Prof. D.M. Joubert (Van der watt 1988:16). The Faculty of Theology now had its own building which housed offices for all the staff and lecture halls which could accommodate all the students. The building was shared with the Faculty of Theology Section A. Section B was housed on the first floor and Section A on the ground floor.

\section{Influence on university, church and society}

One of the important reasons for the establishment of a Faculty of Theology for the Dutch Reformed Church in the northern part of the country was the influence it would have on the university, its students and therefore the society of the future. In its report to the synod of 1937 the Commission stated:

The University of Pretoria is already par excellence the Afrikaner university of the north. That is where Afrikaans speaking students of the Transvaal and the Orange Free State go in their hordes. That is where the most of our Afrikaner teachers are trained. That is where young people are trained to develop the country and create wealth which could be used to uplift the poor. (Verslag 1937:5)

The report continued by stating that a theological faculty at the university would give the church the opportunity to have a huge influence on the Afrikaner people (Verslag 1937:5). This statement underlines the important role which the faculty had form the start. The Dutch Reformed Church stated it clearly from the beginning that one of the main goals of the faculty was to have a positive influence not only on the university, but also on society. That the faculty succeeded in this goal is confirmed by one of the previous rectors, Prof. D.M. Joubert. In his speech at the jubilee of the faculty in 1988, he honoured past lecturers and students for the role which they played and for the influence which they had in the history of the university (Deo Gloria 1988:9). The important role which the faculty played is further emphasised by the report of AKTO (General Synodical Commission for Theological training) tabled at the General Synod of the church in 1998. The report mentioned that members of the commission met with the rectors of the three universities where the church had faculties namely: Pretoria, Bloemfontein and Stellenbosch. During this meeting all three rectors said that theological training was so important to their institutions that they would continue with the faculties even if the church decided to withdraw from a specific university. They emphasised that their institutions would lose a lot if they would lose theological training (Agenda 1998:95). This makes it clear that the faculty did not only serve the church. It had a much wider influence on society as a whole.

\section{Bible translation}

One of the most important contributions that the lecturers of the faculty made was in the field of Bible translation. This is confirmed by a remark by Prof. D.M. Joubert when he said that their contribution to the new Afrikaans translation of the Bible were vital (Deo Gloria 1988:6). The inauguration of the new translation of the Afrikaans Bible in 1983 was an important milestone in not only the history of the Afrikaans speaking churches, but in the history of the Afrikaner community as a whole. The professors of the Faculty of Theology Section B in Pretoria made a huge contribution to this new translation. When the Commission constituted in 1958, Prof. A.H.van Zyl, professor in Old Testament was appointed as secretary of the commission. Prof. E.P. Groenewald was appointed as chair of the commission when Prof. B.B. Keet retired in 1966. Prof. F.J. Botha, A.B. du Toit and W.S. Prinsloo also contributed to the translation. The Kuratorium and the university seconded Prof. van $\mathrm{Zyl}$ on a full time basis to the commission in 1970 so that he could spend all his available time on the project. Borchardt remarked correctly when he stated: 'The faculty played a huge role in this monumental task to translate the Bible in Afrikaans' (Borchardt 1988:49).

\section{A theology professor as Student dean}

'To have a significant influence on the university to the benefit of the Afrikaner people' was one of the important reasons why the Commission of 1937 proposed the establishment of a faculty for the Dutch Reformed Church at the University of Pretoria (Verslag 1937:5). This dream became a reality in 1989 when Prof. P.B. van der Watt, then professor in Church History, was appointed as Student dean at the University of Pretoria (Notule: Dagbestuur van die Kuratorium 1989:1). Van der Watt became professor at the faculty in 1975 and head of the department of Church History when Prof. B.J. Marais retired. He was appointed as dean of the Faculty of Theology in 1987.

Van der Watt played an important role in church and society during his time as professor in Church History and made a major contribution to the field of Church History. He wrote 471 academic and contemporary articles and published 38 books. In recognition for his work, he received the Totius prize for Theology in 1988.

He also served as church leader on different commissions of the Dutch Reformed Church. In 1983 he became assessor of the Synod of Northern Transvaal and became moderator in 1987. It was however not only his influence as church leader and academic which made his contribution one of importance. His involvement with students and student affairs did not go by unrecognised. In 1989 he was appointed as Student dean. In his acceptance of the appointment, Van der Watt stated that he saw his appointment as a continuation of his calling to the Kingdom of God. This is confirmed in a letter to Rev. G.J.C. Venter, secretary of the Kuratorium. Van der Watt wrote: 'I see this new work as a continuation of my calling to work in His kingdom - the terrain is just that much bigger' (Notule: Dagbestuur Kuratoruium 1989:2). Van der Watt continued by describing the spiritual character of his task and how it would be to the benefit of the Dutch Reformed Church. He would be responsible for taking care of more than 20000 students, of who most came from the Dutch Reformed Church. He also said that it was his firm intention 
to preach the gospel whenever the opportunity arrived (Notule: Dagbestuur Kuratorium 1989:2). That the church lost vision of their first intention of 1938 became clear in the administrative chaos which ensued Van der Watt's appointment. Although the Commission for Church Polity of the Synod of Northern Transvaal proposed that Van der Watt retire and therefore keep his status as minister, the executive of the Commission for Church Polity of the General Synod decided otherwise. In their decision they declared: 'The commission is of opinion that you accepted a position outside the church to which there are no ecclesiastical calling' and further:

in the light of the previous mentioned reason the commission regrets to inform you that you cannot keep your status as a minister of the church. (Notule: Dagbestuur Kuratorium 1989:3)

This decision would not keep the new Student dean from doing his work with passion and commitment. What started as a dream in 1937 became an exciting reality.

\section{A theology professor on the Truth and Reconciliation Commission}

The influence of the faculty was not limited to church and university. The staff and students also made a difference in the South African society as a whole. The appointment of Prof.P.J.G. Meiring, professor in Missiology, as a commissioner of the Truth and Reconciliation Commission, confirms this fact.

The Truth and Reconciliation Commission was established shortly after the first democratic election in South Africa in 1994 (Meiring 1999:10). One of the important goals of the commission was to ensure that the newly elected government gave recognition to everybody who was tortured and suffered as victims of human rights offences during the era of apartheid (Du Toit ea 2002:119). Meiring was approached to serve on the commission in 1996. After the university agreed to second him for a period of 18-24 months to the commission, the Kuratorium of the Dutch Reformed Church also agreed because of 'the importance of the matter' (Notule Dagbestuur Kuratorium 1996:1). Meiring's involvement in this process, did not only involve the Dutch Reformed Church, it also involved the University of Pretoria in an important process of healing in a post-apartheid South Africa. It was however especially the church that benefited from Meiring's involvement. After the Moderamen of the church could not come to a decision about a submission before the commission, Meiring intervened. He wrote several letters to the secretary of the General Synodical Commission of the Dutch Reformed Church in which he emphasised the importance of the matter. He pleaded that they should reconsider their position and that the church should take part in a special occasion for religious communities which were being planned in East London for 17-19 November 1997. In one of the letters Meiring wrote: 'My serious advice is that our church must not let this historical opportunity go by' (Du Toit ea 2002:123).
Because of Meiring's unrelentless action Rev. Freek Swanepoel, chairperson of the Synodical Commission was present in East London and the Dutch Reformed Church did not miss the historical opportunity to witness about their role in the wrongs of the past. Although Meiring were often criticised for his role and his involvement in the commission, his presence was an example of how the Faculty of Theology Section B at the University of Pretoria played a major role in broader South African society.

\section{A theology professor assassinated}

The role played by theologians from the faculty and the influence which they had, were not always appreciated. The assassination of Prof. Johan Heyns serves as a shocking example. Heyns paid the highest price on 5 November 1994 when he was murdered by an assassin while playing cards with his grandchildren (Van der Merwe 1996:325). The murderer was never caught and the motive for the murder still remains a secret. Heyns was a brilliant academic who was loved by his students and respected in the academic world. He wrote numerous books and received the Andrew Murray prize three times: in 1981 for Dogmatiek; in 1985 for Teologiese Etiek and in 1989 for Teologiese Etiek 2/1. He played an influential role as church leader and was moderator of the watershed General Synod of 1986 where the policy document Church and Society ${ }^{1}$ was accepted. Heyns received the President's Decoration for Distinguished Service (gold) from the then state president Mr. PW Botha in 1988. This award confirms the huge influence that he had on the university, church and society. It was however ironically this influence which probably led to his death. Lategan remarks correctly:

Johan Heyns sometimes made remarks and took in positions which were not acceptable to everybody. The way in which he died says something about his stature: A prophet is not always welcome. (Lategan 1996:326)

\section{W.D. Jonker wrote in a tribute to Heyns:}

Can it be that he paid the highest price because of his zeal for peace and reconciliation in our country? That we do not know. But if it is true, then he died in the good tradition of the witness, the martyr, whose witness cannot be sealed by anything better than his own blood. (Jonker 1996:327)

The influence of Heyns could not be stopped by a bullet from a rifle. The way in which he died confirmed that the Faculty of Theology Section B made a difference in a sick society.

\section{Research}

The Faculty of Theology did not only influence university, church and society through its personnel. Church and society also benefited from research done at the faculty. One of the important institutes where research on the science of Missiology was done was ISWEN (Instituut vir Sendingwetenskaplike Navorsing) [Institute for Missiological and Ecumenical Research].

1.In Church and society the Dutch Reformed Church officially decided that the church were open to members of all races, that church services could be attended by of apartheid. 


\section{ISWEN (IMER)}

ISWEN was established in 1979 after the General Synod of the Dutch Reformed Church of 1978 identified the need for research in the field of Science of Missiology. The main focus of the institute was to: 'study the mission situation in South Africa and to give advice to the church' (Agenda 1994:237). Dr J.M. Cronje, who also acted as secretary of Missions of the General Synod, was appointed as the first director of the institute (Kotze 1988:76). After the General Synod of 1982, the growth of ISWEN inspired the university to subsidise the institute. The subsidy from the university made it possible to create a position for a permanent researcher which led to the appointment of Dr J.J. Kritzinger as full time senior researcher on 1 January 1986 (Kotze 1988:77). ISWEN was responsible for several pioneering publications. Aan God die dank [Grace to God] part one and two, was a comprehensive work in 2 volumes on the history of missionary work of the Dutch Reformed Church. Since 1982, ISWEN also challenged commissions and congregations of the church to take part in research on missions. This extended the influence of the institute to church and society. The goals of ISWEN broadened in 1986 when it was decided to include research on Ecumenism (Kotze 1988:78). This new development unlocked the world of ecumenism to more research opportunities. Amidst rationalisation at the University of Pretoria which led to the closing of many centres and institutes, it was reported to the General Synod of 1990 that the university was still willing to contribute $70 \%$ of the salary of the Director of ISWEN. This confirms that ISWEN really contributed to academic stature of the university. The work which was done by the institute was enormous. By 1994, 15000 documents had been opened to researchers. As the focus area of ecumenism became more and more important, the name of the institute was changed to the Instituut vir Sendingwetenskaplike en Ekumeniese navorsing [Institute for Missiological and Ecumenical Research] (Agenda 1994:236). By 1998 the activities of the institute expanded in such a way that research was focused on developing methods on how to make diakonia the point of departure for the witness of the church. This meant that confessing the Christian faith became one of the important motivating factors why the church had to take part in the struggle against poverty. The institute was also instrumental in getting young ministers involved in poor communities which in its turn increased the effectiveness of development projects (Handelinge 1998:326). ISWEN was the hands and feet through which the Faculty of Theology Section B contributed in the fight against poverty in the postapartheid South Africa.

\section{Sentrum vir Voortgesette Teologiese Opleiding (SEVTO)}

Coinciding with the establishment of ISWEN was the founding of an important centre namelySEVTO (Sentrum vir Voortgesette Teologiese Opleiding) [Centre for Continuous Theological Training]. One of the important reasons for the establishment of the centre was the need for continuous training of ministers. This became known from the large number of ministers who registered for postgraduate studies but who never completed their studies (Kotze 1988:79). The church gave attention to this matter at the General Synods of 1978 and 1982 and asked the Commission for Ampsbediening en Evangelisasie [Commission for ministry and evangelisation] to investigate the matter (Kotze 1988:79). A study committee was appointed in 1982 to investigate the viability of continuous theological training at the Faculty of Theology Section B. After the different regional synods in Transvaal approved the matter in 1983, the Governing body of the Centre for Continuous Theological Training convened for the first time on 30 January 1984. Dr Malan Nel acted as director on a part time basis. He was succeeded in 1989 by W. Vosloo (Handelinge 1990:412).

The aim of SEVTO was to equip ministers through knowledge and skills for a more effective ministry (Agenda 1990:412). Various courses were developed to reach this goal so that the church could make a difference in society. The courses included biblical and actual themes. Through the training done by SEVTO, the influence of the faculty was carried through to ordinary members of the church who made a difference in society.

\section{The Faculty of Theology in the line of fire}

Although there are a lot of positives surrounding the Faculty of Theology Section B, it was not always plain sailing. Through history, the faculty often found itself in the line of fire. This happened more than once as a result of the viewpoints of some of the lecturers, but political change in South Africa also had an influence.

From its founding, professors ${ }^{2}$ of the faculty became known for their justification of apartheid. Prof. EP Groenewald who became dean of the faculty in 1948 and served in this capacity until 1970 played a prominent role. His report Skriftuurlike grondslag van die beleid van rasse-apartheid en voogdyskap [The Biblical foundation of the policy of race separation and guardianship] became the foundation on which the theology of apartheid was built after it was adopted by the Transvaal Synod of the Dutch Reformed Church in 1948 (Kinghorn 1986:103). This meant that the church gave theological support to the policy of the Nationalist Party government which also came into power in 1948. It is therefore not strange that reaction against the justification of apartheid by some professors of the faculty brought them and the faculty in the line of fire.

\section{Professor B.J. Marais}

One of the first lecturers who came into conflict with the church was Prof. B.J. (Ben) Marais. He was appointed as professor in Church History in 1954. After a lecture at the second assembly of the World Council of Churches in Evanston in 1954, enquiries were made to the Kuratorium 2.Prof. J.H. Kritzinger, prof. $A B$ du Preez and prof. C.W.H. Boshoff also played a prominent role. 
about Marais's political points of view (Borchardt 1988:49). The Kuratorium answered the query from the Presbytery of Langlaagte in November 1954 stating that Marais was in Evanston in his personal capacity and not as a representative of the faculty. After the publication of Vertraagde Aksie: ' $n$ Ekumeniese getuienis uit die Afrikaner kerk [Delayed Action: An ecumenical witness from the Afrikaner church] in which Marais criticised the biblical foundation of apartheid, critique against him became even fiercer. During the Transvaal Synod of 1961 he was severely reprimanded for his contribution. Synod called for the removal of the book from the shelves of bookstores and requested that action should be taken against the writers because they questioned and attacked the policy of church and state (Borchardt 1988:49). Although Marais caused uproar in church circles, the value of his contribution was confirmed by Mr. Nelson Mandela during the General Synod of The Dutch Reformed Church in 1994. When Mandela addressed the synod, he praised Marais as one of the true prophets of the church (Handelinge 1994:536). Mandela recognised that Marais was prepared to oppose the Dutch Reformed Church in her support of the policy of apartheid. Marais's point of view did not only make him unpopular with many supporters of the apartheid policy, but also placed the faculty in troubled waters. Questions were being asked about the influence on so-called liberal theologians on potential ministers of the Dutch Reformed Church. Although Marais was the first professor from the faculty who got into trouble with the church he would certainly not be the last. By the 1980s another group of lecturers followed with the publication of the Hervormingsdaggetuienis [Reformed day witness].

\section{The reformed day witness}

On 5 November 1980, eight lecturers from the Dutch Reformed faculties in Stellenbosch and Pretoria published a witness in Die Kerkbode, the official newspaper of the Dutch Reformed Church. It soon became known as the Hervormingsdaggetuienis [the Reformed day witness]. C.F.A. Borchardt, A.B. du Toit and J.A. Heyns, were the professors from Pretoria who signed the Witness. In the document the lecturers expressed their concern about the inability of the church to fulfil its God given calling to reconciliation in a credible way. The Witness pleaded with officials and members of the church to prayerfully eradicate loveless and racist attitudes and deeds which led to offensive acts. They also called for more urgency with regard to church unity (Van der Merwe 1990:223).

The Witness created a major uproar in the Dutch Reformed Church. At a meeting of the Kuratorium of the Faculty of Theology Section B which took place on 19-20 November 1980, lecturers were requested: 1 . not to make any public statements which could lead to distrust and put the church decisions in jeopardy and 2. not to do it in a organised way in order to imitate official church decisions. The Kuratorium also questioned the method which was used by the lecturers and asked why it was connected to the celebration of Reformation day (Notule: Dagbestuur Kuratorium 19-20 November 1980). The reprimand by the
Kuratorium was however not the end of the matter. At a secret meeting which took place in March 1981 at the Hartbeespoort dam the lecturers were further reprimanded. The meeting which was attended by almost all the ministers of the Dutch Reformed Church in the Transvaal turned into a triumph for the subscribers of the Witness when Prof. Heyns received a standing ovation after his speech. The voice against injustice in the South African society was loud and clear and it came from members of the Faculty of Theology. Although many applauded the point of view taken by the lecturers, more and more questions were being asked by conservative members in the church about the influence on so called liberalists on ministers of the future.

\section{'False doctrine'}

1989 took the accusations against the faculty to a new level. An alumnus of the faculty, Rev. C.F. Heiberg sent a memorandum on false doctrine in the faculty to the chair of the Synodical commission of the Synod of Western Transvaal. In the memorandum Heiberg stated that students have been worried for some time about 'certain aspects of the doctrine' in our faculty (Notule: Dagbestuur Kuratorium 1989:3). Prof. J.H. le Roux's view of scripture was questioned, A.B. du Toit, J.G. van der Watt and P.P.A. Kotze were accused for not correcting a lecture by a guest lecturer, Dr Van Tilburg from the Netherlands; J.A. Heyns was accused of 'making advances towards Rome' and P.J.G. Meiring was condemned because he said that 'we must see the good in Islam and Hinduism' (Notule: Kuratorium 1989:4). The memorandum was signed by 12 students. The matter was passed on to the Kuratorium and they requested the dean, Prof. W.S. Prinsloo to organise colloquies between the lecturers and the students. In the meanwhile, although Heiberg withdrew the charge against the lecturers, he continued to use the pulpit to accuse them and the faculty of liberalism. Not everybody was pleased with Heiberg. In reaction, the church council of his congregation, Rant en Dal, wrote a letter to the Presbytery of Krugersdorp in which they asked for an urgent solution to the matter. In the letter Heiberg was also requested to refrain from rousing any further suspicion (Notule: Dagbestuur Kuratorium 1990:3). Heiberg however, was not interested in any discussions with the lecturers. This is confirmed by a letter from the secretary of the Kuratorium to the secretary of the Presbytery of Krugersdorp which read as follows:

the executive of the Kuratorium acknowledges the fact that Rev. Heiberg did not respond to an invitation from the Dean to identify specific examples of liberal doctrine by some of the lecturers. The executive has, after discussion with the lecturers come to the conclusion that there is no truth in the allegations against them. (Notule: Dagbestuur Kuratorium 1991:2)

With this statement a rather dark cloud passed by and the case came to a close.

\section{Weathering a political storm}

The nineties are known as the years of political turmoil in South Africa. The faculty of Theology Section B would not escape these troubled waters. The then State President, 
Mr. F.W. de Klerk announced on 2 February 1990 during the opening of Parliament that the ANC was to be unbanned and that Mr. Nelson Mandela would be released from prison (Du Toit ea 2002:111). Negotiations would follow but before the negotiations could start a referendum was held among the white voters of South Africa to decide on the negotiations with the ANC. The referendum took place in May 1992. Three lecturers from the faculty, A.B. du Toit, S.J. Joubert and J.J. Kritzinger found themselves in trouble with conservative members of the church after they made a declaration in which they said that members of the Dutch Reformed Church who subscribed to the decisions of The General Synod had no choice but to vote Yes in the referendum. One of the people who protested was Rev. PS Strumpher. In a letter to the Kuratorium he referred to a declaration of the Synodical commission of the General Synod which stated that it was not the task of the church to advise members to vote yes of no in the referendum. The church did not want to get involved in Party politics (Notule: Dagbestuur Kuratorium 1992:2).

After a brotherly discussion between the Kuratorium and the three lecturers, the storm of critique quieted down. These events were a timely reminder that the faculty through its lecturers and students indeed had an influence on university, church and society. The lecturers tried their utmost to give guidance to students and members of the church with regard to important issues of the day. This often lead to fierce reaction because it challenged members of the church to get out of their comfort zones.

\section{Financial difficulties}

Although the Faculty of Theology grew steadily since its founding in 1938 and the seventies brought extraordinary growth as a result of the Youth to Youth campaign that was launched in the Dutch Reformed Church, the expansion of the faculty could not go on forever. With political change in the country came financial difficulties in many congregations. This fact together with the end to military conscription led to an oversupply of proponents which in its turn negatively affected student numbers in the faculty. By October 1990 there were already 110 proponents who have not been called to congregations. By 1998 this number grew to 180 (Handelinge 1998:97). Student numbers declined rapidly: 1986 saw 373 registered students; 1990 - 329; 1994 - 189; 1996 - 164 and in 1997 only 129 students (Agenda 1998:121). Fewer students put the number of positions for lecturers under severe pressure. This led to a decision that was approved by all four the Transvaal synods: (1) New positions could only be created if all four the synods approved the decision, (2) Before any position could be filled, the executive of the Kuratorium had to consult with the budget commissions of the four Transvaal synods to get their approval and (3) The Kuratorium had to take great care before filling any vacant position (Handelinge 1995:477). The consequence of this decision had a direct impact on the faculty. The Kuratorium decided in 1996 not to fill the vacancies in Church History, Biblical studies, Missiology and Practical Theology (Agenda 1997:121). Although the financial difficulties were a dark cloud that hung over the faculty, it also prepared the faculty for a new era which dawned in 2000 when a merger between Section A and Section $\mathrm{B}$ of the Faculty of Theology took place to form one Faculty of Theology at the University of Pretoria. After a new agreement was negotiated the amalgamation became official on 1 January 2000 when Prof C.J.A. Vos became the first dean of the unified Faculty of Theology at the University of Pretoria.

\section{Conclusion}

Although the Faculty of Theology Section B was partner in Theological training only for part of the 100 years since 1917, it played an important part in the history of theological training at the University of Pretoria. In partnership with the Faculty of Theology Section A, it had a positive influence on the university, the church and South African society through its lecturers, students and research. As such Section B was a proud partner in creating the history of theological training at the University of Pretoria.

\section{Acknowledgements Competing interests}

The authors declare that they have no financial or personal relationships which may have inappropriately influenced them in writing this article.

\section{References}

Borchardt, C.F.A., 1988, Fakulteit en Kerk in Deo Gloria! Teologiese Fakulteit 1938-1988, NGKB, Pretoria.

Du Toit, P.R., ea, 2002, Moeisame Pad na Vernuwing: Die NG Kerk se pad van isolasie en die soeke na nuwe relevansie 1974-2002, CLF, Bloemfontein.

Engelbrecht, S.P., 1953, Geskiedenis van die Nederduitsch Hervormde Kerk van Afrika, HAUM, Pretoria.

Ferreira, O.J.O., 1970, 'Die geskiedenis van die Volksmonumentekomitee', Unpublished MA thesis, University of Pretoria.

Groenewald, E.P., 1946, Na Agt jaar 'n Terugblik in die onstaan en groei van ons Fakulteit, Voortrekkerpers Bpk, Pretoria.

Groenewald, E.P., 1962, Die Teologiese Fakulteit 25 jaar oud- 'n terugblik, Deo Gloria, Pretoria.

Jonker, W.D., 1996, JA Heyns: In Memoriam in Jaarboek van die Ned Geref Kerk Jaargang 1471996.

Joubert, D.M., 1988, 'n Feesboodskap in Deo Gloria! Teologiese Fakulteit 1938-1988, NGKB, Pretoria.

Kinghorn, J. (ed.), 1986, Die NG Kerk en Apartheid, Macmillan, Johannesburg.

Kotze, C.S., 1988, Fakulteit en Universiteit in Deo Gloria! Teologiese Fakulteit 1938-1988, NGKB, Pretoria.

Kritzinger, J.H., 1946, Die Behoeftes van ons Teologiese Fakulteit, Voortrekkerpers Bpk, Pretoria.

Lategan, L.O.K., 1996, JA Heyns: In Memoriam in Jaarboek van die Ned Geref Kerk Jaargang 1471996.

Meiring, P.J.G., 1999, Kroniek van die Waarheids en Versoeningskommissie, Carpe Diem, Pretoria.

Nicol, W., 1946a, By die Aanvang, Voortrekkerpers Bpk, Pretoria

Nicol, W. (red.), 1946b, Die Ontstaan en Groei van ons Teologiese Fakulteit en huldebetoon aan die Grondlegger Prof GM Pellissier, Voortrekkerpers Bp, Pretoria.

Van der Merwe, G., 1996, JA Heyns In Memoriam in Jaarboek van die Ned Geref Kerk Jaargang 1471996.

Van der Merwe, J.M., 2013, 'Die reis van die Ned Geref Kerk oor 75 jaar: 1938-2013', in D.J. Human \& J.M. en Van der Merwe (reds.), Die Ned Geref Kerk en Teologiese opleiding aan UP: 1938-2013, Universiteit van Pretoria, Pretoria.

Van der Watt, P.B., 1987, Die Ned Geref Kerk: 1905-1975, NGKB, Pretoria.

Van der Watt, P.B. (red.), 1988, Deo Gloria! Teologiese Fakulteit 1938-1988, NGKB, Pretoria.

Van der Watt, P.B., (ed.), 2002, Ad Destinatum IV 1993-2000, Universiteit van Pretoria, Pretoria.

Van Wyk, AA., 1946, Wat die Teologiese Fakulteit vir my beteken het, Voortrekkerpers Bpk, Pretoria. 


\section{Unpublished sources}

Hofmeyer, J.W., 1971, Geskiedenis van die Teologiese Fakulteit van die Ned Geref Kerk aan die Universiteit van Pretoria vanaf 1938-1970 Ongepubliseerde BD skripsie, Universiteit van Pretoria.

Van der Merwe, J.M., 1990, 'Ras, Volk en Nasie' en 'Kerk en Samelewing' as beleidstukke van die Ned Geref Kerk, 'n kerk-historiese studie. DD-proefskrif, Universiteit van Pretoria.

Van der Watt, P.B., 2007, Curriculum Vitae, Pretoria.

Dagbestuur van die Kuratorium van die Teologiese Fakulteit: Notule November 1989
Dagbestuur van die Kuratorium van die Teologiese Fakulteit: Notule November 1990 Dagbestuur van die Kuratorium van die Teologiese Fakulteit: Notule 21 Februarie 1991 Dagbestuur van die Kuratorium van die Teologiese Fakulteit: Notule 20 Januarie 1992 Dagbestuur van die Kuratorium van die Teologiese Fakulteit: Notule 28 September 1995 Dagbestuur van die Kuratorium van die Teologiese Fakulteit: Notule 1 Maart 1996 Dagbestuur van die Kuratorium van die Teologiese Fakulteit: Notule 26 September 1996 Verslag van die Sinodale Kommissie van die die Sinode van Transvaal. 1935

Verslag van die Sinodale Kommissie in sake Teologiese Opleiding aan die Sinode van Transvaal. 1937 


\section{Appendix 1}

\section{Agendas and Acts of synods}

Agenda van die Twaalfde Synode der Ned Herv of Geref Kerk van Zuid Afrika. Pretoria. 1919.

Agenda van die Vyfde Vergadering van die Algemene Sinode van die Ned Geref Kerk. Bloemfontein. 1978.

Agenda vir die Agste Vergadering van die Algemene Sinode van die Ned Geref Kerk. Bloemfontein. 1990.

Agenda vir die Negende Vergadering van die Algemene Sinode van die Ned Geref Kerk Pretoria. 1994.

Agenda vir die Veertiende Vergadering van die Sinode van Noord Transvaal. Pretoria. 1995.
Agenda vir die Tiende Vergadering van die Algemene Sinode van die Ned Geref Kerk. Pretoria. 1998.

Handelingen van die Elfde Synode der Nederduitsch Hervormde of Gereformeerde Kerk van Zuid Afrika. Pretoria. 1916.

Handelingen van de Dertiende Synode der Ned Herv of Geref Kerk van Zuid Afrika. Pretoria. 1922.

Handelingen van de Sewentiende Sinode van die Ned Herv of Geref Kerk van Suid Afrika. Pretoria. 1934.

Handelinge van die Agtiende Sinode van die Ned Herv of Geref Kerk van Suid Afrika. Pretoria. 1937.

Handelinge van die Vierde gewone Vergadering van die Sinode van Oos Transvaal van die Ned Geref Kerk. Pretoria. 1995.

Handelinge van die Tiende Vergadering van die Algemene Sinode van die Ned Geref Kerk. Pretoria. 1998. 